\title{
Disruptive Learning Media Integrated E-Generator Practice System to Advance Self-Efficacy Learners Levels in Era of Education 4.0
}

\author{
https://doi.org/10.3991/ijim.v16i04.28993 \\ Nurul Ulfatin ${ }^{1}$, Andika Bagus Nur Rahma Putra ${ }^{1(\bowtie)}$, Yee Mei Heong ${ }^{2}$, \\ Azizatus Zahro ${ }^{1}$, Anita Dwi Rahmawati ${ }^{3}$ \\ ${ }^{1}$ Universitas Negeri Malang, Malang, Indonesia \\ ${ }^{2}$ Universiti Tun Hussein Onn Malaysia, Johor, Malaysia \\ ${ }^{3}$ Universitas Brawijaya, Malang, Indonesia \\ andika.bagus.ft@um.ac.id
}

\begin{abstract}
This study aims to: (1) develop disruptive learning innovations through the e-generator practice system; (2) testing the feasibility of disruptive learning innovation through the e-generator practice system; and (3) testing the effectiveness of disruptive learning innovations through the e-generator practice system to increase the level of student self-efficacy in the education era 4.0. This study uses the R\&D method with the ADDIE model and ends with a quasi-experimental method. Validation with two teams of experts (online learning media experts and learning software experts). Data analysis with hypothesis testing using SPSS 21.0. The results of this study include: (1) developing disruptive learning innovations through the e-generator practice system covering analysis, design, development, implementation, and evaluation; (2) the results of the product feasibility test validation are $90.1 \%$ (user benefit aspect), 90.5\% (application display aspect), 93.8\% (aspect of information novelty), 97.6\% (content aspect), $90.6 \%$ (aspects of ease of use), $91.5 \%$ (aspects of competency achievement); and (3) disruptive learning innovation through the e-generator practice system has been proven to be effective in increasing the level of self-efficacy of students in the education era 4.0 as evidenced by the results of hypothesis analysis.
\end{abstract}

Keywords - disruptive media, self-efficacy, education 4.0, learning media, educational innovation background

\section{$1 \quad$ Introduction}

The disruptive era has given rise to innovations in the world of education. Especially vocational education that is oriented towards producing graduates to be ready to work in industry, this is unavoidable. The disruptive era marked by the emergence of various learning technologies makes traditional learning increasingly eroded. Various authorities have not optimally realized the impact of this in the world of education 
[1], [2]. In the world of vocational education, this can positively impact if it can adapt well for learning effectiveness. The effectiveness of vocational learning is in line with various digital content as a product of digital technology. Digital learning as a digital technology product has changed the paradigm of the concept of learning so far [3], [4]. The concept of digital learning is defined as the integration of various digital technologies in all aspects of learning. An essential aspect of digital learning starts from the use of digital technology in the learning planning process. Learning planning is carried out by applying technology in various essential components of the learning plan starting from the standard of competency achievement to the assessment process. Furthermore, digital learning in the learning process is carried out by using digital technology in various learning activities. Finally, in the aspect of learning evaluation, it is carried out by using learning technology to assess the advantages and disadvantages of planning and implementing the learning carried out [5], [6].

Technology-based learning media is developing very rapidly in the era of disruptive learning [7]-[9]. The digital learning media used increases the effectiveness and efficiency of achieving learning objectives. Especially in vocational education, learning media can increase the attractiveness and interactivity of the meaningfulness of student learning. Learning media in this era is the most prominent and often used learning website. Learning with the use of websites can support online learning with unlimited access. This makes it easier for students to access a variety of exciting material content. So that technological developments can be followed by vocational education students with the ease of using website-based learning media. Learning technology in the 4.0 education era affects improving the quality of education graduates [10]-[12]. This is because students can follow various technological developments quickly. In addition, students can directly feel the use of developing technology so that the student experience will increase, accompanied by an increase in student competence and capability in learning. Vocational education students are prepared to enter the world of work with good creativity and adaptability. This is certainly influenced by the use of learning technology used. They are learning technology in the 4.0 education era as an actual response to the influence of the industrial era 4.0.

Student self-efficacy becomes a real and serious problem with the impact of digital technology in learning [13]-[15]. The readiness of students in digital learning is not all evenly distributed. This is due to differences in the maturity of students' self-efficacy. Self-efficacy is significantly influenced by the availability of facilities and infrastructure that support the learning process. This is directly proportional to the increase in motivation accompanied by an increase in self-efficacy. So it can be said that the use of digital technology in learning to support the smooth learning process is significant for increasing self-efficacy. The development of online course learning media technology has become a concrete feature of the modern learning era [16]-[19]. In modern learning, various free and paid online courses have emerged with all the conveniences of learning methods. However, so far, various online courses on the internet have not fully adopted various learning theories. So that the effectiveness of learning has not been achieved optimally, so it can be said that the ease of learning online through an online course platform does not fully have a good effect to support learning. Various exposures to the development of digital learning in the 4.0 education era and its impact must 
be immediately found concrete solutions. In addition, the main problem so far that has become the focal point of increasing learning effectiveness is the problem of student self-efficacy. Therefore, this study aims to increase student self-efficacy by utilizing the latest technology in digital learning based on online courses by using websites for training with an e-generator practice learning system.

\section{Methods}

This research was conducted using a research design with the Research and Development (R\&D) method. The research design chosen was using the ADDIE model. In the final stage, a quasi-experimental test was conducted to measure effectiveness. This model consists of five stages in the development of a product. These five stages include analysis, design, development, implementation, and evaluation. This model was chosen because the research objectives are to produce products that can be developed in detail and comprehensively based on needs analysis. This model allows the development of online courses more simply and effectively. The stages carried out in the ADDIE model provide feedback and continuous product improvement. The ADDIE model carried out in this study is fully presented in Figure 1 below.

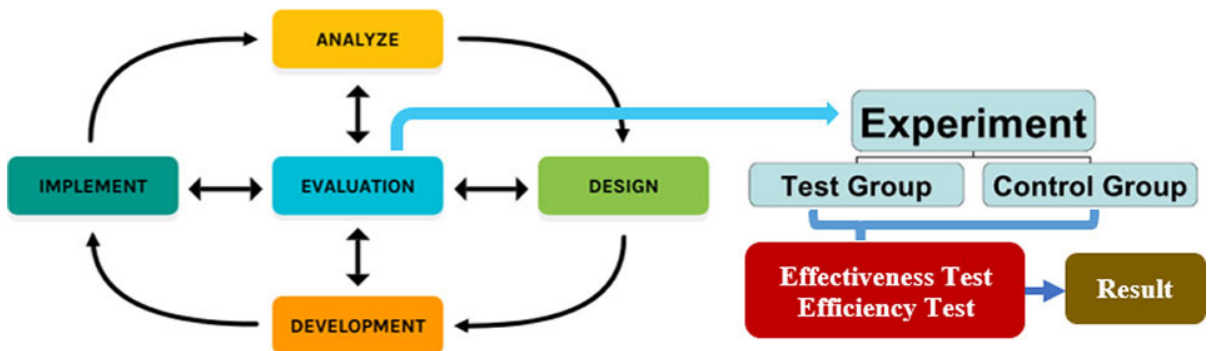

Fig. 1. Stages of research using the ADDIE model and ends with a quasi-experimental

Based on Figure 1 shown above, it can be seen that there are five stages of research. At the analysis stage, mapping activities of student needs and defining student learning problems are carried out in research. Furthermore, at the design stage, adjustments are made to research objectives, planning the instructional design of learning media, identifying equipment availability, and designing course topics. Web-based online course development activities are carried out at the development stage with validation by two experts, user-interface experts, and e-learning experts. At the implementation stage, trial activities were carried out on research subjects using quasi-experimental research. In the evaluation stage, evaluation activities of reports generated from previous research stages are carried out, which are used as the basis for product improvement and updating. Data collection in this study was carried out with expert validation instruments and test instruments for product trials. The data analysis consisted of quantitative descriptive data analysis for expert validation results and parametric inferential analysis in the form of a t-test for product test data. 


\section{$3 \quad$ Results and discussion}

The results of research and development of the ADDIE model are related to product validity and product effectiveness. In this discussion, two significant research results are described: the validity of disruptive learning media integrated e-generator practice system products and the effectiveness of disruptive learning media products integrated e-generator practice systems for advanced self-efficacy learners' level in the era of education 4.0.

\subsection{Product validity of disruptive learning media integrated e-generator practice system}

The product that has been developed is a mobile-based application. This application has several excellent features. The superior features are the material of self-efficacy theory, components of increasing self-efficacy, and strategies to increase efficacy for educators and students. Furthermore, the main page display of the e-generator practice system application is shown in Figure 2.
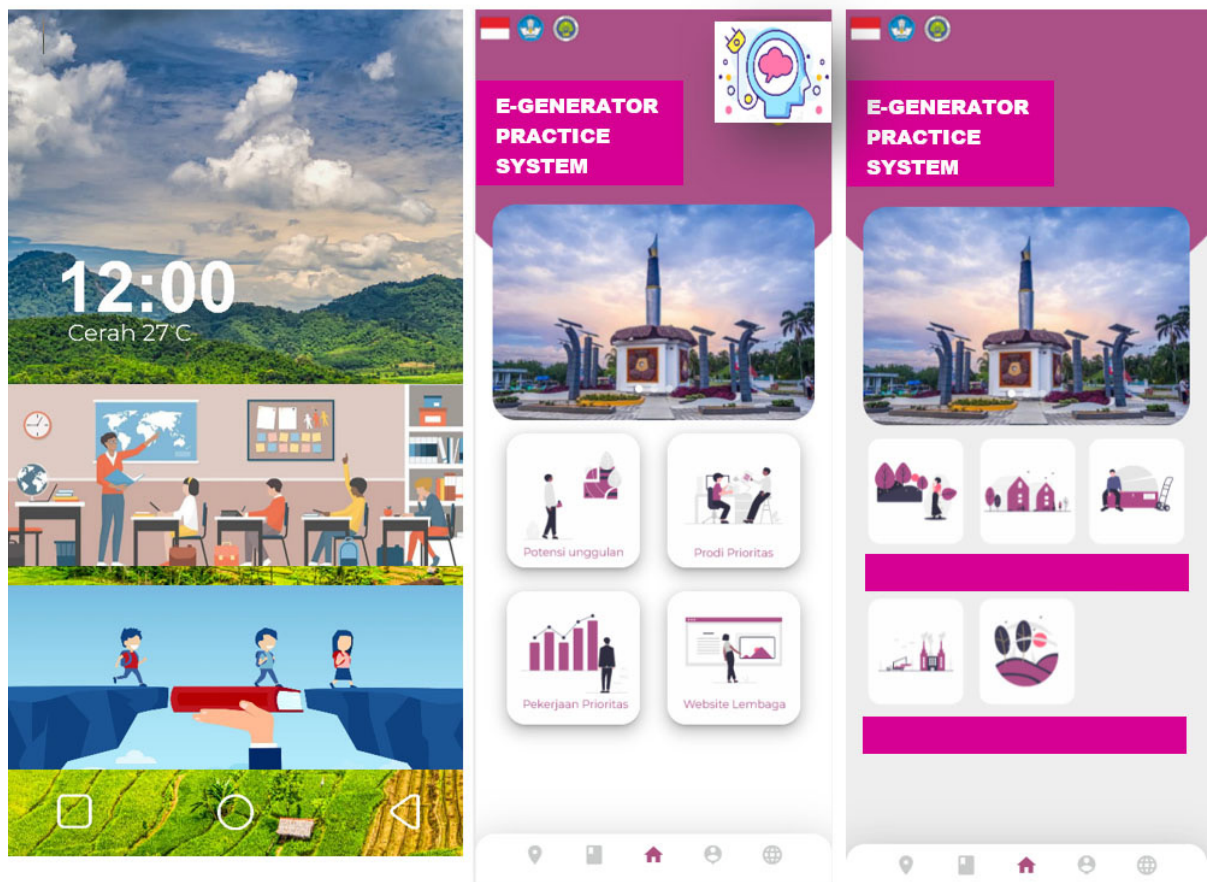

Fig. 2. Stages of research using the ADDIE model and ends with a quasi-experimental 
The validity of the media product developed in this case is a disruptive learning media integrated e-generator practice system consisting of six main aspects. The six aspects are user benefits, aspects of application display aspects of information novelty, aspects of content, ease of use, and aspects of competency achievement. More details are shown in the table below.

Table 1. Details of sub instrument development

\begin{tabular}{|l|l|c|}
\hline \multicolumn{1}{|c|}{ No } & \multicolumn{1}{|c|}{ Item } & Score \\
\hline 1 & Material delivery rate & 92.5 \\
\hline 2 & Conformity with development goals & 86 \\
\hline 3 & Developed product characteristics & 86 \\
\hline 4 & The persuasiveness of the product to users & 90 \\
\hline 5 & Problem solving impact level & 96 \\
\hline & Average & 90.1 \\
\hline
\end{tabular}

Based on Table 1, it can be seen that there are five test items on the aspect of user benefits. The items include the level of delivery of the material, suitability with development objectives, characteristics of the product developed, the level of persuasiveness of the product to users, and problem-solving impact. The validity test results related to user benefits, such as Table 1, can be concluded that the learning media integrated e-generator practice system developed has valid results without revision with an average score of 90.1 .

Table 2. Application display aspect

\begin{tabular}{|l|l|c|}
\hline \multicolumn{1}{|c|}{ No } & \multicolumn{1}{|c|}{ Item } & Score \\
\hline 1 & Display system user interface & 92 \\
\hline 2 & Product system menu & 96 \\
\hline 3 & System sub menu & 86.5 \\
\hline 4 & Step display on system & 84 \\
\hline 5 & System design concept selection & 94 \\
\hline & Average & 90.5 \\
\hline
\end{tabular}

Based on Table 2, there are five test items on the application display aspect. The test items include the user interface system display, product system menu, system submenu, step display on the system, and system design concept selection. The validity test results related to application display aspects such as Figure 2 show that the learning media integrated e-generator practice system developed has valid results without revision with an average score of 90.5 . 
Table 3. The aspect of information novelty

\begin{tabular}{|l|l|c|}
\hline \multicolumn{1}{|c|}{ No } & \multicolumn{1}{|c|}{ Item } & Score \\
\hline 1 & Relevant latest information & 94 \\
\hline 2 & Understanding of users processing information & 90.5 \\
\hline 3 & The level of ease of users to absorb information & 90.5 \\
\hline 4 & Relevant to development goals & 100 \\
\hline 5 & Information validity level & 94 \\
\hline & Average & 93.8 \\
\hline
\end{tabular}

Based on Table 3, there are five test items on the aspect of information novelty. These items include the latest relevant information, understanding of users processing information from the system, the ease of users absorbing information, relevant to development objectives, and the level of validity of the information. The validity test results related to aspects of information novelty show that the learning media integrated e-generator practice system developed has valid results without revision with an average score of 93.8 .

Table 4. Content aspect

\begin{tabular}{|l|l|c|}
\hline \multicolumn{1}{|c|}{ No } & \multicolumn{1}{|c|}{ Item } & Score \\
\hline 1 & Relevant to learning objectives & 100 \\
\hline 2 & The system is easy to operate and use & 98 \\
\hline 3 & The system helps the user in the learning process & 98 \\
\hline 4 & The level of ease of the system as a means of communication & 100 \\
\hline 5 & Power level User interest to further develop the system & 92 \\
\hline & Average & 97.6 \\
\hline
\end{tabular}

Based on Table 4, there are five test items on the content aspect. These items include relevant to learning objectives, and the system is easy to operate and use, the system helps users in the learning process, the level of ease of the system as a means of communication, and the level of user interest in developing the system further. The validity test results related to content aspects show that the learning media integrated e-generator practice system developed has valid results without revision with an average score of 97.6.

Table 5. Aspects of ease of use

\begin{tabular}{|l|l|c|}
\hline \multicolumn{1}{|c|}{ No } & \multicolumn{1}{|c|}{ Item } & Score \\
\hline 1 & The attractiveness of the system view for users & 94.5 \\
\hline 2 & The ability of the system to create user learning motivation & 92 \\
\hline 3 & System ability to activate user knowledge & 94 \\
\hline 4 & System capabilities can help the system understand the material & 84.5 \\
\hline 5 & The level of ease of the system can be learned more by the user & 88 \\
\hline & Average & 90.6 \\
\hline
\end{tabular}


Based on Table 5, there are five test items on the ease-of-use aspect. These items include the attractiveness of the system display for users, the ability of the system to create user learning motivation, the ability of the system to activate user knowledge, the ability of the system to help the system understand the material, and the level of ease of the system can be learned more by the user. The validity test results related to the easeof-use aspect can be concluded that the learning media integrated e-generator practice system developed has valid results without revision with an average score of 90.6.

Table 6. Aspects of competency achievement

\begin{tabular}{|l|l|c|}
\hline \multicolumn{1}{|c|}{ No } & \multicolumn{1}{|c|}{ Item } & Score \\
\hline 1 & The level of encouragement on the user to learn more about the system & 88 \\
\hline 2 & The driving force of the system to influence the user is getting more motivated & 86.5 \\
\hline 3 & Ease of application of the system at all levels & 98 \\
\hline 4 & The level of ease of system repair when trouble occurs & 92,5 \\
\hline 5 & System compatibility presents menus and icons & 92.5 \\
\hline & Rata-rata & 91.5 \\
\hline
\end{tabular}

Based on Table 6, there are five test items in the aspect of competency achievement. These items include the level of encouragement for users to learn more about the system, the impetus for the system to influence users to be more motivated, the ease with which the system is applied at all levels, the level of ease with which the system is repaired when trouble occurs, and the suitability of the system in presenting menus and icons. The results of the validity test related to aspects of competency achievement can be concluded that the learning media integrated e-generator practice system developed has valid results without revision with an average score of 93.8. So that the overall innovation of learning media in the form of an online training system developed has a high validity score according to the concept of developing learning media.

\subsection{Product effectiveness of disruptive learning media products integrated e-generator practice system to advanced self-efficacy learners level in an era of education 4.0}

The effectiveness of the disruptive learning media product integrated e-generator practice system to advance self-efficacy learners level in the era of education 4.0, which was developed, was tested by comparing two experimental class and control classes. More details are presented in Table 7. 
Table 7. Test the hypothesis of the assessment data

\begin{tabular}{|l|l|c|c|c|c|c|}
\hline \multicolumn{9}{|c|}{ Independent Samples Test } \\
\hline & & \multicolumn{2}{|c|}{ Levene's Test } & \multicolumn{3}{|c|}{ t-test for Equality of Means } \\
\hline \multirow{2}{*}{ Result } & F & Sig. & $\begin{array}{c}\text { Sig. } \\
\text { (2-Tailed) }\end{array}$ & $\begin{array}{c}\text { Mean } \\
\text { Difference }\end{array}$ & $\begin{array}{c}\text { Std. Error } \\
\text { Difference }\end{array}$ \\
\hline & $\begin{array}{l}\text { Equal variances } \\
\text { assumed }\end{array}$ & 3.82 & 0.05 & 0.02 & 6,774 & 2,902 \\
\cline { 2 - 7 } & $\begin{array}{l}\text { Equal variances not } \\
\text { assumed }\end{array}$ & & & 0.03 & 6,774 & 2,9880 \\
\hline
\end{tabular}

Based on Table 7, the results of hypothesis testing using the t-test concluded that there was a difference in self-efficacy between the group of students who used learning media in the form of disruptive learning media integrated e-generator practice system and the control group that did not use the developed media product. This is because the significance value is below 0.05 . So it can be said that the developed media products are proven to be statistically effective. The discussion on the validity and effectiveness of the disruptive learning media integrated e-generator practice system in this study is divided into three sub-discussions: increasing learner self-efficacy in the education 4.0 era and the effectiveness of the e-generator practice system in increasing self-efficacy, and the effect of using the system. e-generator practice in the era of disruptive learning.

\subsection{Increasing student self-efficacy in the era of education 4.0}

Self-efficacy is a determining component of student success in learning [20]. Increasing self-efficacy in the education 4.0 era must be a concern for all components of education. Especially in the field of vocational education, this is very important for the progress of a nation. High self-efficacy vocational education graduates can increase capabilities in the world of work. In the world of work, the industry has implemented a new policy to welcome industry 4.0. So that modern learners who can adapt have a high potential for success. Therefore, increasing student self-efficacy in the education 4.0 era is very important to develop. The development of self-efficacy needs to pay attention to the needs and problems of students in learning [21]-[23]. Internal and external factors influence the needs and problems of students in learning. These two factors are generally influenced by the school environment and outside the school. Especially in the school environment, it is closely related to the quality of learning carried out by teachers and students. An interactive and innovative learning approach can increase students' self-efficacy in learning in the education 4.0 era. Various activities that involve the active role of students are needed to increase self-efficacy. This activity is in online training by prioritizing learning styles and advances in digital technology in the education 4.0 era. So that it can be said that by meeting students' needs and solving problems, they will increase self-efficacy effectively. This is related to the use of digital technology in learning based on various online media content presented efficiently but has a good depth of material.

The development and use of digital technology in an online training website can increase student self-efficacy in the education 4.0 era. The developed practice learning 
e-generator system has benefits for users. Good learning media must be easy to use but have good material as well. The use of media is necessary for achieving the learning objectives as determined when learning planning [24]. Some experts state that self-efficacy consists of two components, namely personal efficacy and general efficacy. Personal efficacy is the belief that one has the ability. At the same time, efficacy is generally related to a person's belief that environmental factors determine his success. So it can be concluded that efficacy in character education is a combination of personal and general efficacy. People who believe they can do something have the potential to change events in their environment, prefer to act, and are closer to success than those with low self-efficacy. [25], [26].

\subsection{The effectiveness of the e-generator practice system in increasing self-efficacy}

The effectiveness of using the e-generator system in increasing students' self-efficacy is proven through this research. The use of digital technology in learning makes it easier for students to access learning materials more freely [27]-[29]. The student experience will be better if the learning media used is by their expectations. Especially in vocational education, experiential and theoretical learning in the classroom is combined with increasing self-efficacy. So that online learning media is very appropriate as an effective solution for preparing superior graduates. The practice e-generator system provides convenience services for students to increase their self-efficacy. This system allows for monitoring student learning outcomes at any time. This is very important for increasing student self-efficacy; continuous monitoring needs to be carried out [30]. Barriers faced by students can be controlled through this system. This system can provide input related to student problems and their solutions. More personalized learning allows for better self-efficacy improvement. It can be explained that students who understand more about learning orientation and collaboration between students in online learning will impact success in learning [31].

Someone who has high self-efficacy has higher expectations and sets higher goals for their learning outcomes. For example, an educator makes more effort when teaching and persists in helping the learning process of their students. The effectiveness of using an e-generator system is closely related to that. Self-efficacy possessed by an educator can make educators prefer to act, have more desire to try new teaching ideas and strategies that can improve the learning process of their students, and persist in helping the learning process of their students [32]-[34]. Self Efficacy becomes an important study in learning because it is an important skill to increase achievement, in this case, students. It can also be said that self-efficacy is the primary motive for learning because, without belief in one's ability, one will not try to improve oneself. Some experts claim that humans can regulate their behavior by changing cognitive responses and self-regulating how they will treat themselves. Indirectly, the use of the e-generator system can improve the social life of students. The social life in the surrounding environment also dramatically influences how a person thinks and acts, especially in matters relating to self-efficacy [35], [36].

The disruptive era emphasizes the importance of continuing education that focuses on developing the quality of graduates [37], [38]. The development of the quality of 
graduates in this era can be done by using website-based learning media. Website-based learning media can increase student independence and learning outcomes [39]. This increase can occur due to the ease of access to materials and the flexibility of student learning. Various ways of student learning can be well accommodated through the e-generator practice system in the era of disruptive learning. Students' success in completing online training courses is determined by two main factors, namely, online learning experience and internet connection [40]. So far, web-based online training has advantages over traditional methods. This is because students can improve their learning experience better than traditional learning methods. The success of the website-based online training developed has a high success because it has validity and effectiveness. It can be explained that the effects of the developed online training have technical quality, information quality, service quality, and student satisfaction by the principles of website-based online course development. [41], [42]. Therefore, it can be concluded that the difference in student self-efficacy between those who use the e-generator practice learning system and those that do not indicate the influence of learning media developed in the era of disruptive learning.

\section{Conclusion}

The learning media products developed have a high level of validity and effectiveness. This is known from the results of expert validation of web-based learning media with an average score of $90.1 \%$ (user benefit aspect), 90.5\% (application display aspect), 93.8\% (aspect of information novelty), 97.6\% (content aspect), 90.6\% (aspects of ease of use), $91.5 \%$ (aspects of competency achievement). In addition, the e-generator practice system developed is statistically proven to increase students' self-efficacy. The development of the quality of instructors and collaboration between students is a serious concern for the further development of website-based learning media.

\section{Acknowledgment}

The research team expresses their deepest gratitude to LP2M State University of Malang, providing funding for the 2021 UM PNBP. We also express our deepest gratitude to the Automotive Engineering Education study program, which has always provided support for facilities and infrastructure.

\section{References}

[1] R. Feitknecht and J. Lovey, "Vocational Training and Education in the Library and Information Professions in Switzerland: An Overview and Some Reflections," Innov. Instruments Community Dev. Commun. Educ., pp. 161-172, 2021. https://doi.org/10.22618/ TP.PCMS.20216.360011

[2] S. Billett, S. Choy, and S. Hodge, "Enhancing the standing of vocational education and the occupations it serves: Australia," J. Vocat. Educ. Train., vol. 72, no. 2, pp. 270-296, 2020. https://doi.org/10.1080/13636820.2020.1751247 
[3] N. Mbanga and V. N. Mtembu, "Digital learning: perceptions of lecturers at a technical vocational educational and training college," South African J. High. Educ., vol. 34, no. 4, 2020. https://doi.org/10.20853/34-4-3656

[4] R. Naidoo and T. Dawuwa, "Technology integration in tvet colleges in a semi-urban area," in EDULEARN19 Proceedings, 2019, vol. 1, pp. 10634-10641. https://doi.org/10.21125/ edulearn.2019.2707

[5] M. Subandi, S. Suhartadi, P. Partono, and A. Putra, "PjBL-MOOCs As Future Models for Vocational High Schools," JPP (Jurnal Pendidik. dan Pembelajaran), vol. 27, no. 2, pp. 65-72, 2021. https://doi.org/10.17977/um047v27i22020p065

[6] A. B. N. R. Putra et al., "The innovation of intelligent system e-consultant learning to improve student mindset of vocational education in the disruptive Era 4.0," J. Phys. Conf. Ser., vol. 1833, no. 1, p. 16, 2021. https://doi.org/10.1088/1742-6596/1833/1/012033

[7] B. E. Dasilva et al., "Development of android-based interactive physics mobile learning media (IPMLM) with scaffolding learning approach to improve HOTS of high school students," J. Educ. Gift. Young Sci., vol. 7, no. 3, pp. 659-681, 2019. https://doi.org/10.17478/ jegys.610377

[8] N. Yuniarti, A. L. Setiawan, and D. Hariyanto, "The development and comprehensive evaluation of control system training kit as a modular-based learning media," TEMJ., vol. 9, no. 3, pp. 1234-1242, 2020. https://doi.org/10.18421/TEM93-52

[9] Z. Qalbi and R. F. Putera, "The effect of learning media and linguistic intelligence on storytelling ability," Int. J. Sci. Technol. Res., vol. 9, no. 1, pp. 711-714, 2020.

[10] S. Ghosh, A. Muduli, and S. Pingle, "Role of e-learning technology and culture on learning agility: An empirical evidence," Hum. Syst. Manag., vol. 40, no. 2, pp. 235-248, 2021. https://doi.org/10.3233/HSM-201028

[11] Q. Liu, S. Geertshuis, and R. Grainger, "Understanding academics' adoption of learning technologies: A systematic review," Comput. Educ., 2020. https://doi.org/10.1016/ j.compedu.2020.103857

[12] T. Bøe, K. Sandvik, and B. Gulbrandsen, "Continued use of e-learning technology in higher education: a managerial perspective," Stud. High. Educ., 2020. https://doi.org/10.1080/ 03075079.2020.1754781

[13] S. S. Piro and H. M. Ahmed, "Impacts of antenatal nursing interventions on mothers' breastfeeding self-efficacy: An experimental study," BMC Pregnancy Childbirth, vol. 20, no. 1, 2020. https://doi.org/10.1186/s12884-019-2701-0

[14] M. W. Shehzad, S. A. Lashari, A. Alghorbany, and T. A. Lashari, "Self-efficacy Sources and Reading Comprehension: The Mediating Role of Reading Self-efficacy Beliefs," 3 L Lang. Linguist. Lit., vol. 25, no. 3, pp. 90-105, 2019. https://doi.org/10.17576/3L-2019-2503-07

[15] P. Udayanan, "The role of self-efficacy and entrepreneurial self-efficacy on the entrepreneurial intentions of graduate students: A study among omani graduates," Entrep. Bus. Econ. Rev., vol. 7, no. 4, pp. 7-20, 2019. https://doi.org/10.15678/EBER.2019.070401

[16] M. D. B. Castro and G. M. Tumibay, "A literature review: efficacy of online learning courses for higher education institution using meta-analysis," Educ. Inf. Technol., vol. 26, no. 2, pp. 1367-1385, 2021. https://doi.org/10.1007/s10639-019-10027-Z

[17] H. Yan, F. Lin, and Kinshuk, "Including Learning Analytics in the Loop of Self-Paced Online Course Learning Design,” Int. J. Artif. Intell. Educ., 2020. https://doi.org/10.1007/ s40593-020-00225-Z

[18] M. G. Gómez-Zermeño, "Massive open online courses as a digital learning strategy of education for sustainable development," J. Sustain. Dev. Energy, Water Environ. Syst., vol. 8, no. 3, pp. 577-589, 2020. https://doi.org/10.13044/j.sdewes.d7.0311 
[19] A. Sadaf, F. Martin, and L. Ahlgrim-Delzell, "Student perceptions of the impact of quality matters-certified online courses on their learning and engagement," Online Learn. J., vol. 23, no. 4, pp. 214-233, 2019. https://doi.org/10.24059/olj.v23i4.2009

[20] K. Filippou, "Students' academic self-efficacy in international master's degree programs in finnish universities," Int. J. Teach. Learn. High. Educ., vol. 31, no. 1, pp. 86-95, 2019.

[21] M. Trautner and M. Schwinger, "Integrating the concepts self-efficacy and motivation regulation: How do self-efficacy beliefs for motivation regulation influence self-regulatory success?," Learn. Individ. Differ., vol. 80, 2020. https://doi.org/10.1016/j.lindif.2020.101890

[22] A. Alhadabi and A. C. Karpinski, "Grit, self-efficacy, achievement orientation goals, and academic performance in University students," Int. J. Adolesc. Youth, vol. 25, no. 1, pp. 519-535, 2020. https://doi.org/10.1080/02673843.2019.1679202

[23] Y. Chen, "Correlation between self-efficacy and english performance," Int. J. Emerg. Technol. Learn., vol. 15, no. 8, pp. 223-234, 2020. https://doi.org/10.3991/ijet.v15i08.13697

[24] M. Ediyani, U. Hayati, S. Salwa, S. Samsul, N. Nursiah, and M. B. Fauzi, "Study on development of learning media," Budapest Int. Res. Critics Inst. Humanit. Soc. Sci., vol. 3, no. 2, pp. 1336-1342, 2020. https://doi.org/10.33258/birci.v3i2.989

[25] A. B. N. R. Putra et al., "The innovation of disruptive learning media with augmented reality based 3D object concept with drill machine design to improve quality of distance learning in the era of education 4.0," Int. J. Interact. Mob. Technol., vol. 15, no. 12, p. 193, 2021. https:// doi.org/10.3991/ijim.v15i12.21579

[26] T. T. Kiong, K. E. Roslen, A. B. N. R. Putra, and Y. M. Heong, "Sains Insani eISSN : [ 01277871 ] Pembangunan Modul Pengajaran Berasaskan Permainan Digital Bagi," Sains Insa., vol. 6, no. 1988, pp. 139-143, 2021. https://doi.org/10.33102/sainsinsani.vol6nol.263

[27] M. Barisone et al., "The effectiveness of web-based learning in supporting the development of nursing students' practical skills during clinical placements: A qualitative study," Nurse Educ. Pract., 2019. https://doi.org/10.1016/j.nepr.2019.02.009

[28] V. Mkrttchian, I. Krevskiy, A. Bershadsky, T. Glotova, L. Gamidullaeva, and S. Vasin, "Web-based learning and development of university's electronic informational educational environment," Int. J. Web-Based Learn. Teach. Technol., vol. 14, no. 1, pp. 32-52, 2019. https://doi.org/10.4018/IJWLTT.2019010103

[29] A. M. Al-Abdullatif, "Alternative assessment approaches and quality product design within web-based learning environments," Int. J. Web-Based Learn. Teach. Technol., vol. 15, no. 3, pp. 60-74, 2020. https://doi.org/10.4018/IJWLTT.20200701.oa1

[30] P. Peura et al., "Trajectories of change in reading self-efficacy: A longitudinal analysis of self-efficacy and its sources," Contemp. Educ. Psychol., vol. 64, 2021. https://doi. org/10.1016/j.cedpsych.2021.101947

[31] F. Han and R. Ellis, "Personalised learning networks in the university blended learning," Comunicar, vol. 28, no. 62, pp. 19-30, 2020. https://doi.org/10.3916/C62-2020-02

[32] H. P. Wiratraman and S. Lafrance, "Protecting Freedom of Expression in Multicultural Societies: Comparing Constitutionalism in Indonesia and Canada," Yuridika, vol. 36, no. 1, p. 75, 2021. https://doi.org/10.20473/ydk.v36i1.24032

[33] A. Astri Muliasari, R. Kemala Dewi, H. Fatchur Rochmah, A. Rakoto Malala, and P. Gamawati Adinurani, "Improvement Generative Growth of Coffea arabica L. Using Plant Growth Regulators and Pruning," E3S Web Conf., vol. 226, p. 00003, 2021. https://doi. org $/ 10.1051 / \mathrm{e} 3$ sconf $/ 202122600003$

[34] M. Anis and C. Anwar, "Self-organized learning environment teaching strategy for ELT in Merdeka Belajar concept for high school students in Indonesia," JEES (Journal English Educ. Soc., vol. 5, no. 2, pp. 199-204, 2020. https://doi.org/10.21070/jees.v5i2.869

[35] F. Tentama and M. Z. Nur, "The correlation between self-efficacy and peer interaction towards students' employability in vocational high school," Int. J. Eval. Res. Educ., vol. 10, no. 1, pp. 8-15, 2021. https://doi.org/10.11591/ijere.v10i1.20573 
[36] X. Wu, "Application of artificial intelligence in modern vocational education technology," J. Phys. Conf. Ser., vol. 1881, no. 3, 2021. https://doi.org/10.1088/1742-6596/1881/3/032074

[37] T. Tillmanns, "Learning sustainability as an effect of disruption," Environ. Educ. Res., vol. 26, no. 1, pp. 14-26, 2020. https://doi.org/10.1080/13504622.2019.1682125

[38] P. Ajibade and S. M. Mutula, "Virtual learning: a disruptive service in academic libraries," Libr. Hi Tech News, vol. 38, no. 1, pp. 12-13, 2021. https://doi.org/10.1108/ LHTN-07-2020-0067

[39] J. Ikhsan, M. Akhyar, and M. K. Nais, "The effects of science-on-web learning media on junior high school students' learning independency levels and learning outcomes," J. Turkish Sci. Educ., vol. 16, no. 2, pp. 231-239, 2019.

[40] G. Muhametjanova and A. Akmatbekova, "The web-based learning environment in general physics course in a public university in Kyrgyzstan," Eurasia J. Math. Sci. Technol. Educ., vol. 15, no. 3, 2019. https://doi.org/10.29333/ejmste/100409

[41] A. B. N. R. Putra, A. Mukhadis, and N. Ulfatin, "Augmented reality (AR ) press machine as the application of the latest learning media technology in the XXI Century," J. Phys. Conf. Ser. Pap., vol. 19, no. 1, pp. 1-7, 2021.

[42] A. Mukhadis et al., "The innovation of learning plan designer based mobile web to improve quality of learning media in vocational technology for education 4.0," J. Phys. Conf. Ser., vol. 1833, no. 1, pp. 1-7, 2021. https://doi.org/10.1088/1742-6596/1833/1/012030

\section{Authors}

Nurul Ulfatin is a professor at the Universitas Negeri Malang, Indonesia. She actively conducts research in the field of social humanities education. She is an active speaker in national and international seminars. She has published many scientific books and articles and is indexed by reputable indexers.

Andika Bagus Nur Rahma Putra is a productive young lecturer at the Universitas Negeri Malang, Indonesia. He is active in writing scientific papers, re-searching, and developing learning technology. He also owns more than 150 educational copyrights and often conducts international collaborative research.

Yee Mei Heong is a productive and active young lecturer at Tun Hussein Onn University Malaysia, Malaysia. She is active in writing scientific articles and reference books on vocational education. She has participated in many national and international activities. She is also active as a resource person and speaker in international activities.

Azizatus Zahro is a lecturer at the Universitas Negeri Malang, Indonesia. Apart from being a lecturer, She also serves as the head of the center for gender and health. She is active in various national and international social activities. She has produced many scientific works. She is also active as a speaker at seminars related to gender and health.

Anita Dwi Rahmawati is an active postgraduate student at Brawijaya University. She is active in research and social activities in the health education. She has written many scientific works in the form of books. She actively participates in national and international seminars.

Article submitted 2021-12-19. Resubmitted 2022-01-09. Final acceptance 2022-01-10. Final version published as submitted by the authors. 